\title{
EKOKRITIK PADA NOVEL KEKAL KARYA KALU KANCANA SERTA PEMANFAATANNYA DALAM PEMBELAJARAN SASTRA DI SMA
}

\author{
Yenny Fatimah, Herman J. Waluyo, Budi Waluyo \\ Universitas Sebelas Maret \\ E-mail: yennyfth@gmail.com
}

\begin{abstract}
Abstrak: Representasi kehidupan manusia yang tergambar di dalam karya sastra dapat hadir dalam berbagai macam bentuk, salah satunya berkenaan dengan lingkungan. Ekokritik merupakan teori kritis dalam pendekatan mutakhir untuk mengkritik sebuah wacana yang bertema lingkungan. Penelitian ini bertujuan untuk mendeskripsikan: (1) ekokritik yang terkandung dalam novel Kekal karya Jalu Kancana; (2) nilai pendidikan karakter yang terkandung dalam novel Kekal karya Jalu Kancana; dan (3) relevansi novel Kekal karya Jalu Kancana sebagai bahan ajar sastra di Sekolah Menengah Atas. Penelitian ini dilaksanakan dengan metode penelitian kualitatif deskriptif dan pendekatan ekokritik. Sumber data berupa dokumen dalam bentuk novel dan informan yang terdiri dari peserta didik dan guru. Subjek penelitian diambil dengan teknik purposive sampling. Pengumpulan data dilakukan dengan analisis dokumen dan wawancara. Uji validitas yang digunakan yaitu triangulasi sumber data dan triangulasi metode. Teknik analisis data yang digunakan adalah analisis model mengalir. Hasil penelitian ini menunjukkan bahwa: (1) tema yang diangkat dalam novel adalah lingkungan serta banyak menyoroti ekokritik antropogenik meliputi: penjamahan cagar alam, perusakan dan pembukaan hutan, perusakan lingkungan, perdagangan karbon, dan ketidakpedulian terhadap hewan liar dan habitatnya; (2) nilai pendidikan karakter yang terkandung dalam novel meliputi religius, kerja keras, mandiri, gemar membaca, peduli lingkungan, peduli sosial dan tanggung jawab; dan (3) novel Kekal relevan dijadikan materi pembelajaran jika dilihat dari keterkaitannya dengan tujuan instruksional yang harus dicapai, juga dari aspek isi, penyajian, bahasa, dan kegrafikaan. Dengan demikian dapat disimpulkan bahwa hasil penelitian ini dapat memberi kontribusi terhadap perkembangan ekokritik di Indonesia. Selain itu, hasil penelitian ini memberikan gambaran tentang pentingnya memberikan pendidikan karakter terhadap peserta didik, utamanya mengenai peduli lingkungan.
\end{abstract}

Kata kunci: ekokritik, novel Kekal, nilai pendidikan karakter, relevansi dengan pembelajaran.

BASASTRA Jurnal Bahasa, Sastra, dan Pengajarannya

Volume 9 Nomor 2, Oktober 2021, P-ISSN 2302-6405, E-ISSN 2714-9765 


\title{
ECOCRITICS IN THE NOVEL TITLE KEKAL BY KALU KANCANA AND ITS UTILIZATION IN LEARNING LITERATURE IN SENIOR HIGH SCHOOL
}

\begin{abstract}
The representation of human life depicted in literary works can come in various forms, one of which relates to the environment. Ecocriticism is a critical theory in the latest approach to criticizing a discourse with environmental themes. The representation of human life depicted in literary works can come in various forms, one of which relates to the environment. Ecocriticism is a critical theory in the latest approach to criticizing a discourse with environmental themes..The purposes of this research are to describe: (1) ecocriticism in the novel Kekal by Jalu Kancana; (2) character educational values in the novel Kekal by Jalu Kancana; and (3) the relevance of novel Kekal by Jalu Kancana as literature teaching material in Senior High School.This research was conducted by descriptive qualitative method and using an ecocriticism approach. Data sources are in the form of documents whis is novel and informants consist of students and teachers. The research subject was taken using purposive sampling technique. Data was collected by document analysis and interviews. The validity test used is triangulation of data sources and triangulation of methods. The data analysis technique used is flow model analysis. The results of this study indicate that: (1) the theme raised in the novel is the environment and focuses on anthropogenic ecocriticism, including: exploitation of nature reserves, forest destruction, environmental destruction, carbon trading, and indifference to wild animals and their habitats; (2) the value of character education contained in the novel includes religious, hard work, independent, likes to read, cares about the environment, cares about socialism and responsibility; and (3) novel Kekal is relevant to be used as learning material if it is seen from its relation to the instructional objectives that must be achieved, as well as from the aspects of content, presentation, language, and graphics. Thus, it can be concluded that the results of this study can contribute to the development of eco-criticism in Indonesia. In addition, the results of this study provide an overview of the importance of providing character education to students, especially regarding environmental care.
\end{abstract}

Keywords: ecocriticism, novel Kekal, the value of character education, relevance to learning.

\section{PENDAHULUAN}

Karya sastra di dalam masyarakat memiliki beberapa fungsi esensial yang memengaruhi perkembangan dan peradaban manusia, sebab karya sastra lahir dari representasi kehidupan manusia. Emzir dan Rohman (2016: 9) mengutip pendapat Wellek dan Warren, menjelaskan setidaknya ada lima fungsi yang dimiliki sastra di tengah lingkungan masyarakat, yaitu: sebagai hiburan, bahasan pembelajaran, bahan renungan, media komunikasi simbolik, dan sebagai pembuka paradigma berpikir. Esten (2013: 35) memaparkan pemilihan tema-tema yang diungkapkan para sastrawan amat dipengaruhi dan ditentukan oleh berbagai persoalan kemasyarakatan dan zaman pada kurun waktu tertentu. Representasi kehidupan manusia yang tergambar di dalam karya sastra dapat hadir dalam berbagai macam bentuk, 
salah satunya berkenaan dengan lingkungan.

Dewasa ini, banyak sekali terjadi perusakan lingkungan di Indonesia. Hal ini dapat dilihat dari data yang disampaikan Maha \& Masbar (2018: 320) yakni berkurangnya hutan Indonesia dari 186.544 ha (1950) menjadi 81.299 ha (2013). Perusakan ligkungan dalam skala kecil juga terlihat dari hasil penelitian Taslin, dkk. (2018: 269) yang menunjukkan hanya $10 \%$ peserta didik SMP N 1 Siompu yang membuang sampah pada tempatnya. Kedua data tersebut cukup mewakili keadaan masyarakat Indonesia masih sangat minim untuk menjaga kelestarian lingkungan.

Pemaparan di atas selaras dengan fokus pada penelitian ini yakni, ekoritik dan nilai pendidikan karakter pada novel Kekal karya Jalu Kancana serta relevansinya sebagai bahan ajar sastra. Kekal merupakan sebuah novel yang mengisahkan petualangan tokoh Alit dan kawankawannya dalam berusaha mengkonservasi Cagar Alam Kamojang. Cerita berkembang dan menggambarkan kerusakan-kerusakan alam yang terjadi di Pulau Sumatera dan Pulau Jawa. Selain sasrat dengan kritik lingkungan, novel Kekal juga sarat dengan nilai-nilai pendidikan karakter yang sesuai dengan 18 karater yang dipaparkan oleh Kemdikbud (2010). Artinya, novel Kekal dapat digunakan untuk mencapai tujuan penyelenggaraan pendidikan karakter seperti yang diungkapkan Mulyasa (2012: 9) yakni guna menaikkan kualitas, pelaksanaan, dan hasil pendidikan sehingga peserta didik memiliki akhlak mulia dan karakter yang seimbang, terpadu, dan utuh sesuai dengan SKL pada masingmasing satuan pendidikan.

Penelitian terkait hal di atas pernah dilakukan oleh Juanda (2019) dengan judul penelitian Ekokritik Film Avatar Karya James Cameron Sarana Pendidikan Lingkungan Siswa. Hal yang membedakan penelitian tersebut dengan penelitian yang sekarang adalah pada penelitian ini objek kajian berupa novel, sehingga terdapat perbedaan dalam teknik pengumpulan data. Selain itu, penelitian ini juga mengkaji nilai-nilai pendidikan karakter yang terkandung dalam novel. Penelitian ini dilaksanakan dengan tujuan untuk menjelaskan dan mendeskripsiskan: (1) bagaimana ekokritik yang terkandung dalam novel Kekal karya Jalu Kancana; (2) nilai-nilai pendidikan karakter yang terkandung dalam novel Kekal karya Jalu Kancana, dan (3) relevansi novel Kekal karya Jalu Kancana sebagai bahan ajar sastra di Sekolah Menengah Atas.

Campbell (2010: 13) mengatakan meskipun ekokritik mulai berkembang pada awal tahun 1990-an, ide mengenai ekokritisme sudah 
dieksplorasi oleh beberapa kalangan berpendidikan dalam bentuk berbagai macam artikel. Ekokritik adalah kemampuan untuk mengkritik wacana yang ada, artefak budaya, bentuk dan genre, dan mengeksplorasi alternatif lingkungan sastra (Endraswara, 2016: 2). Garrard dalam kumpulan jurnal Fatchul Mu'in dan Sainul Hermawan (2013: 296) mengkategorikan ekokritik ke dalam enam konsep utama, yakni: (a) pencemaran (pollution), (b) hutan belantara (wilderness), (c) bencana (apocalypse), (d) perumahan/tempat tinggal (dwelling), (e) binatang (animals), dan (f) bumi (earth).

\section{Dalam Undang-Undang}

Nomor 20 Tahun 2003 tentang Sistem Pendidikan Nasional dirumuskan bahwa pendidikan karakter/budi pekerti adalah usaha sadar dan terencana untuk membangun/ membentuk kepribadian yang baik yang bercirikan kejujuran, tangguh, cerdas, kepedulian, bertanggung jawab, kerja keras, pantang putus asa, tanggap, percaya diri, suka menolong, mampu bersaing, profesional, ikhlas bergotong-royong, cinta tanah air, amanah, disiplin, toleransi, taat, dan lain-lain perilaku yang berahlak mulia. Jokilehto (2018: 36) menyatakan bahwa memberikan nilai terhadap suatu hal menyiratkan perbandingan, sedangkan perbandingan ini dapat menunjukkan nilai suatu hal adalah sama atau berbeda jika dibandingkan dengan hal lain

$$
\text { Romansyah (2016: }
$$
menyatakan kriteria pemilihan bahan ajar mencakup penentuan aspek-aspek perilaku yang terdapat dalam standar kompetensi dan kompetensi dasar, serta penentuan atau pemilihan jenis bahan ajar sesuai dengan aspek-aspek perilaku yang terdapat dalam standar kompetensi dan kompetensi dasar. Dalam hal ini penggunaan novel sebagai bahan ajar sastra pada kelas XII Sekolah Menengah Atas sesuai dengan Kurikulum 2013 KD 3.8 menafsir pandangan pengarang terhadap kehidupan dalam novel yang dibaca dan KD 3.9 menganalisis isi dan kebahasaan novel.

\section{METODE}

Penelitian ini merupakan penelitian kualitatif deskriptif, sebab memanfaatkan cara-cara penafsiran dengan menyajikannya dalam bentuk deskripsi (Ratna, 2015: 46) dengan menggunakan teori ekokritik sastra. Sumber data yang digunakan dalam penelitian ini berupa dokumen dan informan. Dokumen yang digunakan dalam penelitian ini yaitu berupa novel Kekal karya Jalu Kancana. Data yang dikumpulkan dalam penelitian ini berupa kata, kalimat, atau ungkapan yang menggambarkan kritik lingkungan dalam novel Kekal karya Jalu Kancana. Informan dalam penelitian ini terdiri dari guru dan 
peserta didik yang telah membaca novel Kekal karya Jalu Kancana. Data yang diperoleh dari informan berupa hasil wawancara dengan informan.

Pengambilan subjek penelitian dilakukan dengan teknik pengambilan data purposive sampling, sampel diambil berdasarkan kriteria yang sudah ditentukan oleh peneliti sesuai dengan tujuan penelitian. Sampel yang diambil berupa data-data yang diperlukan mengenai kritik lingkungan (ekokritik), nilai pendidikan karakter, dan relevansinya sebagai bahan pembelajaran apresiasi sastra di SMA. Penentuan informan dalam penelitian ini dipilih informan dengan pengetahuan dan pengalaman di bidang sastra.

Teknik pengumpulan data dari penelitian ini dilakukan dengan analisis dokumen dan wawancara, sesuai dengan sumber data yang digunakan. Teknik analisis dokumen dilakukan dengan membaca dan mencatat dalam kartu data untuk mengumpulkan data dari novel Kekal karya Jalu Kancana. Teknik wawancara dilakukan untuk mendapatkan data dari informan yang mendukung penelitian ini. Wawancara yang dilakukan bersifat terbuka untuk memperoleh informasi terkait kritik lingkungan, nilai pendidikan karakter, dan relevnasi novel Kekal karya Jalu Kancana. Uji validitas data dalam penelitian ini dilakukan dengan menggunakan triangulasi sumber data dan triangulasi metode. Triangulasi metode dalam penelitian ini dilakukan untuk memeriksa kebenaran data hasil analisis dokumen dengan menggunakan wawancara.

Analisis data dalam penelitian ini menggunakan teknik analisis data model mengalir, yang terdiri dari 4 langkah, yakni: (1) pengumpulan data dengan membaca novel Kekal karya Jalu Kancana yang dilakukan oleh peneliti dan informan, peneliti juga mengumpulkan data dari informan dengan melakukan wawancara; (2) meduksi data, dari data-data yang telah terkumpul peneliti memilih halhal yang pokok, memfokuskan pada hal-hal yang penting, dicari tema dan polanya; (3) menyajikan data dengan cara menyusun data yang telah direduksi secara teratur dan terperinci sehingga mudah dilihat dan dipahami; dan (4) menarik simpulan dari hasil analisis data yang diperoleh.

\section{HASIL DAN PEMBAHASAN}

\section{Ekokritik dalam Novel Kekal Karya Jalu Kancana}

Ekokritik dalam novel Kekal karya Jalu Kancana tergolong dalam bentuk ekokritik sastra antropogenik, yakni karya sastra yang terfokus pada karya yang menggambarkan kerusakan, kepunahan, kehancuran lingkungan akibat ulah manusia (Endraswara 2016: 45). Secara garis besar, peneliti menemukan lima 
bentuk ekokritik dalam novel Kekal karya Jalu Kancana.

\section{Penjamahan Cagar Alam}

Pengarang, dalam novel Kekal menekankan tentang keawaman dan minimnya pengetahuan masyarakat tentang cara berhubungan dengan cagar alam. Berikut ini adalah beberapa kutipan dalam novel Kekal yang menunjukkan adanya penjamahan cagar alam.

(1) Sebelumnya, kami di sini mau memohon bantuan dan kerja samanya untuk mengabari rekanrekan pengendara motor trail lainnya, supaya tidak lagi berkegiatan di kawasan ini. Saya mohon, Kang (Kancana, 2019: 7).

(2) Direktur utama Perusahaan $P$ sama timnya itu, enggak sengaja terekam waktu mereka survei buat lokasi pembukaan lahan pertambangan di Ciharus! (Kancana, 2019: 55).

Kegiatan balap motor trail dan survei lokasi untuk pembukaan lahan tambang di Ciharus menyebabkan rusaknya struktur tanah, sehingga tandus dan tidak ditumbuhi tumbuhan atau pepohonan. Suara bising dari mesin dan knalpot motor trail juga membuat hewan-hewan yang ada di Cagar Alam Kamojang menjadi terganggu. Suara bising ini dapat mengakibatkan stress terhadap hewanhewan tertentu. Selain itu kegiatan fauna untuk mencari makan, minum, dan berburu akan terganggu karena aktivitas manusia. Pengeboran untuk mengakses panas bumi akan merusak struktur tanah dan batuan.

Melalui konflik ini penulis berusaha memberikan kritik terhadap konflik nyata yang terjadi akibat penerbitan Surat Keputusan Menteri Nomor

SK.25/MENLHK/ SETJEN/PLA.2/1/2018 yang mengubah fungsi dalam fungsi pokok kawasan hutan dari sebagian kawasan Cagar Alam Kawah Kamojang seluas 2.391 ha dan cagar alam Gunung Papandayan seluas 1.991 ha menjadi Taman Wisata Alam (Pranata, 2019: 2). Keserakahan manusia terhadap uang membuatnya lupa akan pentingnya menjaga keseimbangan alam dan menaati peraturan.

\section{Perusakan Hutan dan Pembukaan Lahan}

Berikut ini adalah beberapa kutipan dalam novel Kekal yang menunjukkan adanya perusakan hutan dan pembukaan lahan.

(1) Banyak investor asing yang turut campur tangan dalam pengerukan mineral di sana. Belantara yang lebat; tabungan oksigen umat manusia, diratakan demi perusahaan pertambangan asing. Seluas $10.000 \mathrm{Ha}$ pohon-pohon ditumbangkan, dan tempat tinggal hewan-hewan digusur seolah mereka menjadi pengganggu roda 
ekonomi negara. Mengerikan! (Kancana, 2019 : 33-34).

(2) Tampak di sana kegiatan beberapa orang yang tengah menyulut api di tengah hutan (Kancana, 2019 : 78).

Data di atas menunjukkan penulis ingin menyampaikan bahwa perusakan alam, terutama hutan sudah terjadi dalam kurun waktu yang lama. Penebangan hutan seluas $10.000 \mathrm{Ha}$ dan pembakaran hutan dalam novel Kekal ini menunjukkan kepentingan manusia untuk mengeruk kekayaan alam memberikan dampak yang sangat besar, utamanya bagi flora dan fauna yang seharusnya terjaga keasriannya di cagar alam. Ekokritik berkenaan dengan pembukaan lahan ini sagat relevan dengan keadaan hutan di Indonesia saat ini. Dari 125,9 juta hektar kawasan hutan dan kawasan konservasi perairan, teelah banyak yang mengalami kerusakan. Di Cagar Alam Kamojang saja, pada tahun 2000 telah terjadi penutupan hutan alam dan sekunder sebesar 4861.17 ha (Putikasari, dkk, 2016: 131). Selain kasus nyata tersebut, penebangan hutan di cagar alam Pegunungan Cycloop menyebabkan kawasan tersebut sering diterjang banjir (Romarak P, dkk, 2021 : 448). Melalui ekokritik ini penulis ingin menyampaikan banyaknya dampak buruk perusakan hutan dan pembukaan lahan, seperti hilangnya habitat fauna tertentu, habisnya sumber daya alam, berkurangnya hutan yang mampu menyediakan oksigen, pencemaran udara, dsb.

\section{Perusakan Lingkungan}

Novel Kekal juga menyoroti masalah perusakan lingkungan yang berskala kecil. Hal tersebut dapat dilihat dari kutipan novel kekal berikut.

"Jangankan proses penyediaan air alami yang ada di Cagar Alam Kamojang ini, trotoar dan jalan raya saja jadi banyak berserakan sampah. Puncak dan jalur gemunung pun dipenuhi jutaan sampah plasik bekas para pendaki” (Kancana, 2019: 10).

Gunung Kerinci juga menjadi daerah yang sering menampung sampah plastik hasil peninggalan pendakinya. Hal ini digambarkan oleh penulis pada kutipan:

"O ya, ada lagi puncak tertinggi Sumatra: Gunung Kerinci, di sana bertumpuk-tumpuk sampah di bawah semak cantingginya, sampah-sampah di sepanjang jalur pendakiannya" (Kancana, 2019: 120).

Selain menyebabkan pemandangan menjadi tidak elok, sampah plastik juga membutuhkan waktu yang sangat lama untuk terurai sehingga memengaruhi kualitas tanah. Namun, para pendaki, seperti yang digambarkan dalam novel Kekal tidak 
memiliki cukup kesadaran untuk tidak membuang sampah sembarangan.

\section{Perdagangan Karbon}

Cuplikan yang menunjukkan kagiatan perdagangan karbon, yang menjadikan hutan sebagai komoditas perdagangan, diantaranya:

(1) Ya, di Jambi ini sama di Riau sana marak perdagangan karbon, Lit. Belum pernah dengar? (Kancana, 2019: 104).

(2) Sementara penanaman jenis pohon penyerap karbon di Taman Nasional Barbak itu malah mengurangi hutan alami yang sudah berkurang sebanyak $75 \%$ itu (Kancana, 2019: 105).

\section{Perdagangan}

karbon merupakan kegiatan memperjualbelikan fungsi hutan. Secara sederhana konsepnya adalah, setiap negara yang menghasilkan emisi karbon di atas 5\% memiliki kewajiban untuk mengurangi emisi karbon tersebut. Pengurangan dilakukan dengan menjaga hutan sehingga pohon-pohon yang ada dapat menyerap karbon.

Konsep perdagangan karbon ini merupakan jual beli yang saling menguntungkan. Akan tetapi, pada kenyatannya, keserakahan manusia tidak dapat dibendung, sehingga terjadi penyalahgunaan perdagangan karbon, seperti yang disebutkan dalam novel Kekal. Masalah yang disoroti oleh penulis adalah penanaman jenis pohon penyerap karbon yang berdampak pada berkurangnya hutan alami. Selain itu ada juga oknumoknum yang menyalahgunakan kekuasaan dan wewenang untuk mengorupsi uang hasil perdagangan karbon ini. Tentu saja kebocoran dana ini berdampak pada kurang maksimalnya pelestarian hutan penyerap karbon dan masyarakat di sekitar hutan pun tidak memperoleh kesejahteraan seperti yang telah dijanjikan.

\section{Ketidakpedulian terhadap Hewan} Liar dan Habitatnya

"Lebih buruk lagi, pada video lainnya, kusaksikan seekor gajah ditusuk-tusuk secara sengaja oleh sekelompok orang yang sama. Sorot mata gajah itu seolah memohon belas kasihan kepada manusia-manusia buas yang memperlakukan dirinya sebegitu liarnya" (Kancana, 2019: 80).

Pengarang pada bagian ini memberikan kritik terhadap manusia yang tidak memiliki hati nurani. Secara jelas digambarkan adanya oknum dari pihak safari yang melakukan penyiksaan terhadap gajah dan harimau. Hal ini menunjukkan betapa manusia yang digambarkan dalam novel Kekal tidak peduli terhadap makhluk lainnya.

Di dunia nyata wilayah Sungai Teso dan Nilo merupakan tempat 
pelestarian gajah. Kancana (2019: 151) dalam novelnya menyebutkan "belum lagi dari Pangkalan Kerinci yang memperjuangkan habitat gajah yang terganggu oleh pabrik kertas di wilayah Sungai Teso dan Nilo."

Pengarang membawa masalah yang sebenarnya benar dihadapi di dunia nyata ini ke dalam novelnya untuk menunjukkan rintanganrintangan yang dihadapi dalam melakukan pelestarian gajah akibat adanya pabrik kertas. Habitat gajah semakin menyempit dan sumber makanan mereka semakin menipis. Selain itu, aktivitas manusia menebang pohon, melakukan peng-angkutan, dan kegiatan-kegiatan lainnya juga menyebabkan stress pada gajah bahkan menyebabkan perubahan perilaku gajah.

\section{Nilai Pendidikan Karakter dalam Novel Kekal Karya Jalu Kancana}

Kemendiknas (2010: 9) menyatakan ada 18 aspek nilai-nilai pendidikan karakter. Peneliti menemukan 7 aspek nilai-nilai pendidikan karakter dalam novel Kekal karya Jalu Kancana. Nilai-nilai yang dimaksud adalah sebagai berikut.

\section{Religius}

Religius diartikan sebagai sikap dan perilaku yang patuh dalam melaksanakan ajaran agama yang dianutnya, toleran terhadap pelaksanaan ibadah agama lain, dan hidup rukun dengan pemeluk agama lain (Kemendiknas, 2010: 9).

(1) Kuturuti ucapannya. Lantas kutempelkan dahiku pada karpet masjid (Kancana, 2019: 157).

(2) Aku segera mengambil air wudu, sedang ia menggumandangkan azan. Beberapa makmum berbondong-bondong menjawab pangilan azan tersebut. Melihat mereka seperti itu, aku jadi malu sendiri. Kuingat-ingat sudah berapa lama keningku ini tidak bersujud kepada-Nya (Kancana, 2019: 99).

Kedua cuplikan di atas menunjukkan tokoh Alit yang menunaikan ibadah salat saat di perjalanan. Ia sedang berjuang mencari solusi dan pertolongan atas masalah yang mengancam nyawanya di Pulau Sumatera. Perjalanannya dilakukan dengan hitch hike bahkan untuk tempat beristirahat selalu tidak menentu. Meski demikian ia berusaha untuk tetap menjalankan kewajibannya untuk melakukan ibadah salat. Dari cuplikan tersebut juga tergambar Alit sadar bahwa selama ini ia telah melupakan kekuasaan dan keberadaan Tuhan. Maka, ketika azan berkumandang, Alit memutuskan untuk menunaikan ibadah salat. Selain Alit, penulis juga menggambarkan beberapa makmum yang berbondongbondong menuju masjid dan melaksanakan salat berjamaah. 


\section{Kerja Keras}

Kerja keras memiliki deskripsi sebagai perilaku yang menunjukkan upaya sungguh-sungguh dalam mengatasi berbagai hambatan belajar dan tugas, serta menyelesaikan tugas dengan sebaik-baiknya (Kemendiknas, 2010: 10). Tokoh Alit tetap bekerja keras untuk melanjutkan tujuannya mengkonservasi Kawasan Cagar Alam Kamojang. Ia sadar dampak buruk apa saja yang akan terjadi jika penambagan panas bumi di kawasan cagar alam tersebut diizinkan oleh pemerintah. Maka ia memutuskan untuk pergi ke Sumatera, mencari bantuan anggota IUCN yang dulu menjadi kawan kakeknya. Dalam perjalanannya mencari tiga orang anggota IUCN, Alit menghadapi berbagai macam hambatan.

(1) Pak Murat dan Pak Siam telah meninggal. Satu harapan lainnya masih ada: Pak Oentoeng. Tujuanku selanjutnya berarti Sumatra Barat (Kancana, 2019: 110).

(2) Jumlahnya sekira 250 artikel. Aku berharap, honor yang kutuai nanti benar-benar besar. Sebagiannya akan kukirimkan pada Pерер untuk biaya pengobatan Ibu, sedang sisanya kugunakan untuk pulang (Kancana, 2019: 158).

(3) Kubenarkan ucapan Hassan. Tak sepatutnya aku lekas menyerah atas kegagalan ini. Semestinya, hal tersebut jadi penanda bahwa orang-orang picik seperti mafiamafia tengik ini kerap menyulitkan (Kancana, 2019: 162)

Tiga kutipan di atas menunjukkan selama di Sumatra banyak hal yang membuat Alit semakin jauh dari tujuannya. Pertama, Alit menemui Pak Murat, namun ternyata Pak Murat mendapat fitnah atas pembakaran hutan di Riau dan harus bersembunyi dari kejaran polisi. Meski demikian, ia tidak menyerah, ia malah membantu membersihkan nama Pak Murat, sebagai imbalannya Pak Murat akan membawa kasus Ciharus ke IUCN. Namun sayangnya, sebelum menepati janji, Pak Murat meninggal. Tidak hanya itu, dua orang lain yang dianggap bisa membantunya ternyata tidak bisa membantu Alit. Pak Oentoeng telah meninggal dan Pak Siam mengalami alzeimer, sehingga tidak bisa membantu Alit.

Kegagalan demi kegagalan yang Alit temui tidak membuatnya putus harapan. Ia memutuskan untuk membuat penelitian studi banding sehingga bisa menunjukkan bahwa data menjadi dasar penerbitan SK25 adalah data usang dan tidak benar. Halangan lain datang, ibunya tiba-tiba sakit dan Pepep memintanya untuk pulang. Selain itu, uang yang dimiliki Alit sudah mulai habis. Namun, sekali lagi Alit tidak menyerah. Ia bekerja keras membuat tulisan SEO untuk membayar biaya rumah sakit ibunya 
dan sebagian lagi untuk biayanya hidup di Sumatera. Namun Alit tidak pernah menyerah sehingga perjuangannya membuahkan hasil, seperti terlihat dalam cuplikan berikut, "saat ini, kurasakan beban runtuh dari pundak" (Kancana, 2019: 220).

\section{Mandiri}

Kemendiknas (2010:10) mendeskripsikan mandiri sebagai sikap dan perilaku yang tidak mudah tergantung pada orang lain dalam menyelesaikan tugas-tugas. Tokoh Alit dihadapkan pada situasi yang menuntutnya untuk mandiri. Ayahnya telah meninggal, ibunya sedang bekerja di luar negeri, sedang adiknya tinggal di tempat yang berbeda karena tuntutan pekerjaan. Meski masih berstatus sebagai mahasiswa, namun Alit sudah tidak bergantung 100\% kepada ibunya. Ia mulai kuliah sambil bekerja menjadi penulis SEO untuk menambah uang saku. Hal ini dapat dilihat pada kutipan,

“ 'Renata, sekarang pun aku sudah dapat honor dari tulisan SEO-ku itu,' balasku meredakan kekhawatiran. Meskipun kecilkecilan. Itu cukup untuk uang sakuku” (Kancana, 2019: 27).

Karakter kemandirian juga ditunjukkan tokoh Alit ketika dalam menyelesaikan masalahnya saat mendapat ancaman dari perusahaan P. Awalnya ia berangkat ke Sumatera untuk meminta bantuan, namun pada akhirnya ia menemukan pemecahan masalahnya sendiri melalui saran tokoh Riski yakni dengan membuat sebuah penelitian komparatif. Hal ini terlihat pada kutipan berikut.

"Benar juga yang dikatakannya. Tak berguna jadi corong meminta pertolongan ke sana kemari. Nyatanya aku gagal mendapat simpati IUCN melongok Ciharus. Kuncinya memang riset. Itu memang senjata mutakhir untuk menghadapi sebuah system" (Kancana, 2019: 164).

\section{Gemar Membaca}

Pada novel Kekal, karakter gemar membaca dimiliki oleh tokoh Pepep. Ia mendirikan sebuah perpustakaan pribadi, terlihat pada kutipan berikut. Tempat yang dimaksud adalah perpustakaan milik Pepep (Kancana, 2019: 15).

Tokoh lain yang digambarkan memiliki karakter gemar membaca adalah tokoh Alit. Berikut cuplikan yang menunjukkan kegemaran membaca dari tokoh Alit.

"Enggak sengaja, waktu itu baca buku masakan di Jalan Dewi Sartika” (Kancana, 2019: 31).

Tokoh Pepep dan tokoh Alit memiliki kebiasaan yang baik yakni membaca. Gemar membaca adalah kebiasaan menyediakan waktu untuk membaca berbagai bacaan yang 
memberikan kebajikan bagi dirinya (Kemendiknas, 2010:10). Membaca membuka jendela dunia. Kegemaran membaca akan membuat manusia memiliki pengetahuan dan wawasan yang luas.

\section{Peduli Lingkungan}

Kemendiknas

mendeskripsikan peduli lingkungan sebagai sikap dan tindakan yang selalu berupaya mencegah kerusakan pada lingkungan alam di sekitarnya, dan mengembangkan upaya-upaya untuk memperbaiki kerusakan alam yang sudah terjadi. Novel Kekal memang mengangkat tema konservasi sumber daya alam, maka di dalam novel ini banyak ditemukan nilai pendidikan karakter peduli lingkungan yang dimiliki oleh tokoh-tokohnya.

Nilai pendidikan karakter peduli lingkungan pertama yang dapat dilihat dalam novel ini adalah usaha beberapa tokoh dalam menjaga ekologi. Para tokoh yang terlibat dalam kegiatan Save Ciharus paham bahwa cagar alam hanya diperuntukkan bagi flora dan fauna. Maka, mereka melakukan tindakan menjaga kelestariannya, seperti terihat pada kutipan berikut.

(1) Sebelumnya, kami di sini mau memohon bantuan dan kerja samanya untuk mengabari rekanrekan pengendara motor trail lainnya, supaya tidak lagi berkegiatan di kawasan ini. Saya mohon, Kang (Kancana, 2019: 7).

(2) Maka dari itulah kami terpaksa memasuki kawasan Hutan Ciharus ini karena pengendara motor trail dan para pendaki kerap memasukinya (Kancana, 2019: 8 9).

Para pegiat Save Ciharus menyadari adanya aktivitas manusia memasuki kawasan Cagar Alam Kamojang. Ada beberapa pengendara motor trail yang melakukan balapan dan para pendaki yang memasuki kawasan tersebut. Balapan motor trail ini menyebabkan kerusakan tanah dan kebisingan. Sementara itu, para pendaki meninggalkan sampah plastik yang merusak keasrian Cagar Alam Kamojang. Oleh karenanya, para pegiat Save Ciharus terpaksa melakukan camp di cagar alam tersebut untuk memberi peringatan secara langsung. Mereka memberikan selebaran berisi tentang informasi untuk tidak memasuki kawasan cagar alam dan meminta secara baik-baik agar tidak melakukan aktivitas apapun di dalamnya.

Usaha menjaga ekologi ini juga dilakukan oleh tokoh Kakek, seperti terlihat pada kutipan-kutipan berikut.

"Kata Bapak, itulah penyesalah seumur hidup Kakek, sehingga dua tahun setelahnya, Kakek memutuskan untuk menyelamatkan biosfer di 
Sumatra setelah pensiun dari pekerjaannya. Meradangnya perkebunan sawit di pulau tersebut menjadi alasan Kakek" (Kancana, 2019: 34).

Tokoh Kakek menyadari bahwa biosfer di Sumatera sudah semakin rusak. Perkebunan sawit sejak era penjajahan Belanda terus menjamur memakan hutan-hutan. Tokoh Kakek sadar, jika kegiatan ini terus dilakukan, maka hutan-hutan di Sumatera akan habis. Oleh karenanya, ia bergabung dengan IUCN dan melakukan penelitian flora-fauna di Pulau Sumatera. Kakek dibantu dengan kawan-kawannya berusaha mengumpulkan data-data yang menunjukkan bahwa flora dan fauna juga memiliki hak atas hutan-hutan tersebut. Hasil penelitian-penelitan yang dilakukan Kakek dan kawankawannya, setidaknya dapat menghambat penggundulan hutan di Sumatera.

\section{Peduli Sosial}

Peduli sosial adalah sikap dan tindakan yang selalu ingin memberi bantuan kepada orang lain dan masyarakat yang membutuhkan (Kemendiknas, 2010: 10). Karakter ini terlihat pada tokoh Pepep, seperti pada cuplikan berikut.

"Aku hanya mampu bantu sebesar ini. Sebagian aku sisihkan buat Tama nanti.
Tabunganku habis semua. Ambillah" (Kancana, 2019: 47).

Ketika Alit memutuskan untuk hitchhike dari Bandung ke Sumatera, Pepep memberikan bantuan uang kepadanya. Pada saat itu, Pepep tahu Alit membutuhkan uang untuk biaya perjalanan dan hidupnya di Sumatera. Sedangkan, Tama yang dirawat karena luka tembak juga membutuhkan uang untuk biaya rumah sakit. Sebagai bentuk kepeduliannya, Pepep memberikan uang tabungannya kepada dua temannya yang membutuhkan. Pepep juga menunjukkan karakter peduli sosialnya ketika Ibu Alit sakit, sementara Alit berada di Sumatera. Sekali lagi ia memberikan bantuan secara finansial seperti terlihat dalam cuplikan berikut. Pepep juga merelakan waktunya untuk merawat ibu Alit, terlihat pada cuplikan berikut.

"Dia menunggui Ibu waktu rawat inap di rumah sakit selama satu minggu. Dia juga yang antar Ibu pulang. Pepep anak yang baik. Beruntung kamu punya teman sebaik dia" (Kancana, 2019: 238).

Bukan hanya secara finansial, Pepep juga meluangkan waktu dan tenaganya untuk merawat ibu Alit. Selama seminggu Pepep menunggui ibu Alit di rumah sakit dan mengantarnya pulang setelah perawatan selesai. Hal ini Pepep lakukan tanpa pamrih. Ia tahu Alit memiliki tanggung jawab yang harus 
segera diselesesaikan. Maka dari itu, Pepep merawat Alit, agar bisa meringankan bebannya dan segera menuntaskan tugasnya di Sumatera.

Karakter peduli sosial juga dimiliki oleh tokoh Alit. Hal ini terlihat pada dua cuplikan berikut.

"Penjelasannya membuatku paham bahwa dirinya benarbenar merasa serba salah karena menerima uang dariku tanpa alasan yang jelas" (Kancana, 2019: 128).

Tokoh Kastia memiliki hutang yang cukup besar. Ia dijebak oleh seorang mucikari yang membuatnya menjadi pekerja seks komersial. Mucikari yang meminjamkan uang kepada Kastia meminta bunga yang besar. Hal ini membuat Kastia tidak pernah bisa melunasi hutannya dan terus terjebak menjadi pekerja seks komersial. Mengetahui hal ini, Alit memutuskan untuk menjual ponsel dan laptop yang ia miliki. Alit ingin membantu membebaskan Kastia dari hutang agar ia bisa hidup selayaknya manusia normal.

\section{Tanggung Jawab}

Kemendiknas (2010: 10) mendeskripsikan tanggung jawab sebagai sikap dan perilaku seseorang untuk melaksanakan tugas dan kewajibannya yang seharusnya dia lakukan terhadap diri sendiri, masyarakat, lingkungan (alam, sosial, dan budaya), negara dan Tuhan Yang
Maha Esa. Karakter ini dimiliki oleh tokoh Pepep, seperti terlihat pada cuplikan berikut.

"Aku paham betul, Pepep merasa terbebani oleh hal ini. Sebagai penggagas Save Ciharus, ia pasti merasa bersalah karena telah melibatkan kami semua" (Kancana, 2019: 17).

Pepep merasa bersalah sebab dua kawannya menjadi korban penembakan saat melakukan usaha konservasi Cagar Alam Papandayan. Pepep sebagai penggagas Save Ciharus merasa bersalah dan berniat untuk menghentikan aktivitas Save Ciharus. Ia tidak ingin ada korban lain, terlebih Nugi meninggal akibat insiden tersebut. Ia tidak bisa melindungi kawannya satu demi satu, maka ia memutuskan untuk menyudahi Save Ciharus agar tidak menerima teror dari Perusahaan P lagi.

Karakter bertanggung jawab juga dimiliki oleh tokoh Pak Murat dalam melunasi hutangnya.

"Saya, Nak, punya utang lima ratus rupiah pada Ito dulu. Uang itu saya simpan samapi sekarang. Berdosa saya ... berdosa ... kalau sampai tidak utang itu tiba di tangannya (Kancana, 2019: 87).”

Pak Murat memiliki hutang lima ratus rupiah kepada kakek Alit. Namun karena suatu hal, ia tidak bisa melunasinya hingga saat ia bertemu 
Alit. Setelah mengetahui Alit adalah cucu Ito (kakek Alit), ia segera mengambil uang dan mebayarkannya kepada Alit. Hutang adalah hutang. Ketika Pak Murat meminjam uang, maka pada saat itu juga ia memiliki kewajiban untuk mengembalikannya. Meskipun hutang tersebut sudah lewat bertahun-tahun, Pak Murat tetap mengingatnya hingga datang kesempatan untuk membayarnya.

\section{Relevansi Novel Kekal Karya Jalu Kancana sebagai Bahan Ajar Sastra di Sekolah Menengah Atas}

Berdasarkan pendapat Winkel (2007: 330) bahan ajar dapat berupa naskah, gambar, isi audiocasette, dan lain-lain. Karena digunakan di dalam pembelajaran, maka bahan ajar harus menunjang ketercapaian tujuan pembelajaran dan juga memberikan dampak positif kepada peserta didik.

Dalam penggunaan kurikulum 2013, peserta didik diharapkan dapat memliki kompetensi menafsirkan dan menganalisis isi novel. Setelah membaca novel, peserta didik diharapkakn dapat mengerti isi cerita yang dapat dilihat melalui tokoh, peristiwa, maupun latar yang terdapat dalam novel. Untuk menunjang ketercapaian pembelajaran maka novel yang digunakan juga harus memiliki nilai-nilai yang positif serta dapat mengembangkan kepribadian peserta didik. Oleh sebab itu, bahan ajar novel yang digunakan harus terbebas dari unsur SARA, kekerasan, pornografi, dan nilai penyimpangan yang lainnya.

$$
\text { Novel Kekal karya Jalu }
$$
Kancana memungkinkan dijadikan sebagai bahan ajar pada tingkat SMA sebab sesuai kompetensi dasar yang harus dicapai peserta didik yakni pada KD 3.8 menafsir pandangan pengarang terhadap kehidupan dalam novel yang dibaca dan KD 3.9 menganalisis isi dan kebahasaan novel. Novel kekal juga terbebas dari nilai-nilai negatif atau nilai yang menyimpang. Novel Kekal karya Jalu Kancana kaya akan nilai-nilai positif yang dapat dijadikan pembelajaran dan dicontoh oleh peserta didik. Di samping itu, banyak nilai pendidikan karakter yang sesuai dengan Pemendikbud (2010) sehingga dapat menunjang pembentukan karakter peserta didik yang baik dan mulia. Novel Kekal memiliki sifat menghibur sehingga menarik untuk dibaca dan juga mampu memberikan manfaat kepada pembacanya, sehingga memenuhi prinsip karya sastra, yakni dulce et utile.

Pemaparan di atas diperkuat dengan pendapat Sarweno selaku guru Bahasa Indonesia yang menyatakan novel Kekal karya Jalu Kancana mengandung banyak nilai positif sehingga sesuai atau relevan untuk digunakan sebagai bahan ajar sastra pada tingkat SMA.

"Banyak, banyak sekali nilai pendidikan karakter yang baik 
dari novel ini. Misalnya, yang paling disoroti $y a$, tentang kepedulian terhadap lingkungan. Ada juga tentang disiplin, kerja sama, dan peduli sosial. Ada banyak contoh di novel itu. Nah itu karakter yang baik, atau karakter yang mulia."

Nilai-nilai pendidikan karakter yang terkandung dalam novel merupakan suatu hal yang dapat memberikan dampak positif untuk peserta didik. Sebagai peserta didik, Zahwa Wetikhanza A. Y. dan Zahwa Wetikhanza A. Y. juga mengatakan hal yang sama, yaitu novel Kekal mengandung nilai-nilai yang dapat digunakan sebagai tolak ukur baik dan buruk. Mereka juga mengatakan novel Kekal memiliki banyak nilai pendidikan karakter sehingga novel Kekal sesuai untuk digunankan sebagai bahan ajar sastra.

Sesuai dengan Permendikbud Nomor 8 Tahun 2016, penggunaan buku nonteks, termasuk novel sebagai bahan ajar sastra di tingkat SMA perlu dilihat dari empat aspek. Pertama, aspek materi, yang harus diperhatikan salah satunya adalah mampu memotivasi untuk mengembangkan diri dan mampu menjaga persatuan dan kesatuan bangsa dengan mengakomodasi kebhinekaan, sifat gotong royong, dan menghargai pelbagai perbedaan. Nilai-nilai yang terkandung dalam novel Kekal akan membantu pembentukan kepribadian peserta didik meskipun secara tidak langsung. Seperti yang diungkapkan Suparno sebagai guru Bahasa Indonesia berikut.

"Dalam novel ini kan kritik lingkungan jadi tema utama. Jadi banyak menyoroti tentang perusakan lingkungan terutama perusakan cagar alam. Saya rasa ini sangat bagus jika dijadikan bahan bacaan, jadi selain sebagai media hiburan juga bisa menjadi penambah wawasan, terutama tentang penyelamatan lingkungan."

Uraian materi yang terdapat dalam novel Kekal sesuai dengan judul yang diangkat. Ceritanya juga dapat mencerminkan perjuangan yang dapat memotivasi untuk mengembangkan diri. Disamping itu, usaha para tokoh untuk mengkonservasi cagar alam mencermikan persatuan dan kesatuan bangsa.

Kedua, aspek bahasa, kesesuaian bahasa dengan tingkat perkembangan usia peserta didik perlu diperhatikan. Dari hasil penelitian diketahui bahwa bahasa yang digunakan pengarang dalam novel Kekal dapat dipahami oleh siswa SMA. Hal ini dikarenakan sebagain besar bahasa yang digunakan adalah bahasa Indonesia dan sesuai dengan perkebangan usia peserta didik. Walaupun novel menggunakan Sumatera sebagai latar daerah dengan porsi yang cukup banyak, tetapi 
bahasa daerah yang digunakan hanya sebatas sapaan, sedang selebihnya menggunakan bahasa Indonesia.

Warseno selaku Guru Bahasa Indonesia menyatakan bahwa novel Kekal memiliki bahasa yang baik dan dapat dibaca oleh peserta didik SMA kelas XII.

"Dari segi isi, sudah baik. Bahasanya sederhana, tidak berbelit-belit, apa adanya, dan bisa diterima oleh generasi sekarang, bisa memotivasi dan siswa untuk menjadi pribadi yang mandiri."

Berdasarkan pemaparan di atas, dapat diketahui bahwa secara keseluruhan, peserta didik mampu memahami isi novel Kekal melalui bahasa yang digunakan oleh pengarang. Artinya, pengarang menggunakan bahasa yang komunikatif dan informatif untuk menyajikan novel Kekal sehingga novel tersebut dapat dipahami oleh pembaca dengan mudah. Pembaca dapat memetik amanat, pesan, dan nilai positif yang terkandung di dalam novel tersebut. Selain itu, judul dan subjudul dapat menarik minat membaca peserta didik.

Ketiga, aspek penyajian, kelayakan penyajian materi dapat dilihat dari penggunaan ilustrasi untuk memperjelas materi tidak mengandung unsur pornografi dan nilai penyimpangan lainnya, serta sesuai dengan perkembangan usia peserta didik. Penyajian cerita dalam novel Kekal tidak lengkapi dengan ilustrasi yang sesuai dengan judul, hal ini disebabkan karena karya jenis novel lebih fokus pada isi cerita. Hal ini merupakan hal yang wajar, karena novel pada umumnya memang tidak dilengkapi dengan ilustrasi.

Keempat, aspek kegrafikan, dapat dilihat dari segi fisik buku, antara lain ukuran buku, ukuran huruf, dan penggunaan warna harus disesuaikan dengan tingkat perkembangan usia. Ukuran novel Kekal memiliki ukuran yang normal seperti novel pada umumnya. Penggunan huruf dan ukuran huruf tidak terlalu kecil atau terlalu besar, tetapi masih bisa dibaca dengan jarak normal. Penggunaan warna tidak berlebihan, tidak berwarna-warni, dan sesuai untuk peserta didik SMA. Secara keseluruhan, seperti yang diungkapkan oleh Warseno bahwa novel ini dikemas dengan menarik. Suparno juga menambahkan, ketebalan novel Kekal karya Jalu Kancana tidak masalah untuk peserta didik SMA. Menurutnya, hal itu sudah biasa karena peserta didik SMA sudah terbiasa membaca novel dengan ketebalan seperti novel Kekal.

Berdasarkan pembahasan empat aspek sebelumnya, Warseno menyatakan novel Kekal layak dan sesuai untuk digunakan sebagai bahan ajar ajas sastra di Sekolah Menengah Atas. 


\section{SIMPULAN}

Dalam novel ini, peneliti mengkaji kritik lingkungan yang disampaikan pengarang di dalam novel. Secara garis besar, penulis menemukan lima ekokrtik sastra yang bersifat destruktif. Kelima poin tersebut adalah penjamahan cagar alam, kerusakan hutan dan pembukaan lahan, kerusakan lingkungan, perdagangan karbon, dan ketidakpedulian terhadap hewan liar dan lingkungannya.

Novel Kekal karya Jalu Kancana merupakan karya sastra yang dulce et utile, yaitu menghibur dan mendidik. Novel ini juga mengandung nilai-nilai pendidikan karakter meliputi religius, kerja keras, mandiri, gemar membaca, peduli lingkungan, peduli sosial, tanggung jawab. Nilainilai tersebut dapat ditemui pada perwatakan maupun perilaku tokoh dalam novel.

Novel Kekal karya Jalu Kancan relevan bila digunakan sebagai bahan ajar sastra di sekolah menengah atas karena sesuai dengan kompetensi dasar yang ada. Salah satunya KD 3.9 yang berbunyi "Menganalisis isi dan kebahasaan novel" pada kelas XII. Hal ini berarti bahwa novel Kekal relevan dengan tujuan instruksioanl yang harus dicapai. Sebagai buku nonteks pelajaran, novel Kekal memiliki kelayakan dari aspek isi/materi, penyajian, bahasa, dan kegrafikaan sesuai dengan Permendikbud Nomor 8 Tahun 2016 tentang buku yang digunakan oleh satuan pendidikan.

Hasil penelitian ini dapat memberi kontribusi terhadap perkembangan ekokritik di Indonesia mengingat kajian ini masih baru. Selain itu juga mampu memberikan gambaran tentang pentingnya memberikan pendidikan karakter terhadap peserta didik, utamanya mengenai peduli lingkungan.

\section{REFERENSI}

Champbell, Andrea. (2010). Reading Beyond a Universal Nature: Hopes for the Future of Ecocriticism. Ecocriticism Issue (Washington State University), 8 (1), 1 - 21. Di-peroleh 31 Januari 2021 dari http://www.temple.edu/gradmag

Emzir \& Rohman, S. (2016). Teori dan Pengajaran Sastra. Jakarta: PT RajaGrafindo Persada.

Endraswara, Suwardi. 2016. Ekokritik Sastra. Yogyakarta: Morfalingua.

Esten, Mursal. (2013). Sastra Indonesia dan Tradisi Subkultur. Bandung: CV Angkasa.

Jokilehto, J. (2018). Building the Value of the Cultural Assets: the Heritage. Dossier $n^{o}, 2$ (1), 36 - 45. Diperoleh 15 Februari 2021 dari http://www.lettere.uniroma1.it 
Juanda. (2019). Ekokrtitik Film Avatar Karya James Cameron Sarana Pendidikan Lingkungan Siswa. Jurnal Pendidikan Bahasa dan Sastra UNNES, 8 (1), 1 - 9. Diperoleh 12 Februari 2021 http://journal.unnes.ac.id/sju/in dex.php.jpbsi

Mu'in, Fatchul \& Hermawan, Sainul. (2013). Proceedings:

Literature and Nation Character Building. Banjarmasin: Lambung Mangkurat University.

Mulyasa. (2012). Manajemen Pendidikan Karakter. Jakarta: PT Bumi Aksara.

Panata, Yudha. (2019). Penurunan Status Kawasan Cagar Alam Menjadi Taman Wisata Alam Di Kabupaten Garut Dihubungkan Dengan UndangUndang No 5 Tahun 1990 Tentang Konservasi Sumber Daya Alam Hayati Dan Ekosistemnya Jo UndangUndang No 32 Tahun 2009 Tentang Perlindungan Dan Pengelolaan Lingkungan Hidup. Naskah publikasi Fakultas Hukum Universitas Pasundan. Diperoleh 15 Oktober 2021 http://repository.unpas.ac.id/43 803/

Peraturan Menteri Pendidikan dan Kebudayaan Republik Indonesia Nomor 20 Tahun 2018 tentang Penguatan Pendidikan Karakter pada Satuan Pendidikan Formal. (2010). Jakarta: Balai Pustaka.
Putikasari, V., Dahlan, E. N., \& Prasetyo, L. B. (2016). Analisis Perubahan Penutupan Lahan dan Faktor Sosial Ekonomi Penyebab Deforestasi di Cagar Alam Kamojang. Media

Konservasi, 19 (2), 126 - 140. Diperoleh 15 Oktober 2021 https://doi.org/10.29244/medk on.19.2.\%p

Ratna, N.K. (2015). Teori, Metode, dan Teknik Penelitian Sastra. Yogyakarta: Pustaka Pelajar.

Rihman, M. \& Masbar, R. (2018). Pengaruh Alih Fungsi Lahan Kawasan Hutan terhadap Perekonomian Indonesia. Jurnal Ilmiah Mahasiswa Ekonomi Pembangunan Fakultas Ekonomi dan Bisnis Unsyiah, 3 (3), 318 - 329. Diperoleh 15 Oktober 2021 http://www.jim.unsyiah.ac.id/E $\mathrm{KP} /$ article/view/8927

Romansyah, Khalimi. (2016). Pedoman Pemilihan Dan Penyajian Bahan Ajar Mata Pelajaran Bahasa Dan Sastra Indonesia. Jurnal Logika, 8 (2), 59 - 66. Diperoleh 13 Mei 2021

www.jurnal.unswagati.ac.id

Romarak P., Alfasis, dkk. (2021). Dampak Penebangan Hutan terhadap Bencana Banjir di kawasan cagar alam Pegunungan Cycloop. Community Development Journal: Jurnal Pengabdian Masyarakat, 2 (2), 446 - 452. Diperoleh 15 Oktober 2021 https://journal.universitaspahla 
wan.ac.id/index.php/cdj/article /view/1905

Taslin, Sabrin, dkk. (2018). Kepatuhan Siswa terhadap Tata Tertib Sekolah (Studi pada Siswa SMP Negeri 1 Siompu). Selami IPS, 43 (3), 255 - 270. Diperoleh 15 Oktober 2021 http://ojs.uho.ac.id/index.php/s elami/article/view/8500

Undang-undang RI Nomor 20 Tahun 2003 tentang Sistem

Pendidikan Nasional. (2003). Jakarta: Depdiknas.

Winkel, W.S. (2009). Psikologi Pengajaran. Yogyakarta: Media Abadi. 